\title{
ДУХОВНОЕ РАЗВИТИЕ СОВРЕМЕННОГО ЧЕЛОВЕКА
}

\section{SPIRITUAL DEVELIPMENT OF A MODERN PERSON}

O. Grineva

Summary: This article deals with the problem of the spiritual crisis of society as a whole and the impoverishment of the inner spiritual world of a modern man. The article explains the features of the modern worldview of people and the growing problems. The causes of emotional stress in society and the importance of spiritual development of a person are established.

Keywords: spiritual life, life values, stable beliefs, liberation, taste for perfection.

\section{Гринева Ольга Александровна}

к.ф.н., старший преподаватель, Красноярский государственный педагогический университет

им. В. П. Астафьева gold23@inbox.ru

Аннотация: В данной статье рассматривается проблема духовного кризиса общества в целом и обнищания внутреннего духовного мира современного человека. В статье выяснены особенности современного миропонимания людей и нарастающие проблемы. Установлены причины эмоционального напряжения в обществе и важность духовного развития человека.

Ключевые слова: духовная жизнь, жизненные ценности, устойчивые убеждения, освобождение, вкус к совершенству.

отношения, улаживать конфликты, взращивать мужественность и храбрость, развивать грамотность населения, учиться молиться. Как в России, так и в европейских странах значительно увеличивается рост литературных произведений, отражающий уклад жизни согласно определенной эпохе человечества.

Бесспорен факт, что авторы в своих сочинениях воспевали добродетели человека и укоряли пороки, наставляли людей на духовно-нравственный путь, приводили примеры из жизни, некоторые мотивировали служить Богу. Например, в русской культуре важными трудами, призывающими к духовности, являются: «Домострой» (свод житейских, моральных правил, поучений), «Жития князей». Немецкий теолог Лютер Мартин написал трактат «К христианскому дворянству немецкой нации», перевел Библию с латинского на немецкий язык, считал, что «каждый верующий христианин непосредственно связан с богом и ему нужны посредники в лице священников всех уровней» [2].

Очевидно, церковь занимала ведущую роль в государстве, а следовательно, значительно влияла на духовную жизнь общества. Пробуждался интерес к обучению, не только на дому, но и у священников, а также возлагали надежды на училище и академию, активно печатались и раскупались книги как светского, так и религиозно-нравственного содержания. Под духовной жизнью понимается богобоязненность, религиозная идеология, молитва (обращение к Богу), соблюдение заповедей, правил и норм поведения, трудолюбие, саморазвитие, мягкость, жизнелюбие, доброта, сопричастность Творца всему человечеству, переживания за людей [3].

Однако, XVI - XVII, на примере российского общества, 
характеризуется первым распадом устоявшейся культуры. Время обмирщения культуры, распада целостности государства, разделение церковной и государственной власти, народных мятежей. В литературе появляются первые произведения, в которых описываются духовные муки человека, издевательства купцами над холопами, высмеивание священнослужителей, душевные переживания человека, например, «Повесть о Савве Грудцыне» [3]. Тем временем в европейских странах появляется новое религиозное течение - лютеранство, подвергающее сомнениям и критике Божьи заповеди и их соблюдение. Следовательно, в обществе зарождаются ключевые учения и воззрения, послужившие толчком к переосмыслению имеющихся духовных знаний и ценностей, а также традиционных догматических представлений [4].

Переменам в сфере духовности в XVIII веке способствовали реформы и указы Петра I, а также страсть императора к кутежам. Тяга к прогрессу, как в производстве, так и в образованности высших слоев населения привела к широкому распространению литературы житейского назначения, нерелигиозного содержания, появлению в речи иностранных слов, терминов, стремлению России приблизится к культуре западных стран. Церковные устои начинают восприниматься унылыми, мрачными, значительно возрастает интерес к светскому искусству: музыке, театрам, новым тенденциям в архитектуре.

Примечателен факт, что XIX век на Руси славится открытием школ, гимназий и университетов, продолжается развитие женского образования, возрастает чувство патриотизма в народе, широкую популярность получают научные общества, организуются экспедиции в далекие страны и острова. Русская культура получает название «Золотого века», благодаря выдающимся писателям, таким как А.С. Пушкин, А.И. Герцен, И.А. Гончаров, Ф.М. Достоевский, Л.Н. Толстой. Не смотря на высокое стремление народных масс быть образованными и духовно развитыми людьми, владея иностранными языками и научными знаниями, прекрасно помня слова молитв и соблюдение церковных канонов, веря в небесные силы святых мучеников, в обществе наблюдается несоответствие между нарастающим техническим прогрессом и отсталыми христианскими пережитками [3].

Значительные перемены в духовности русского народа происходят после крестьянской реформы 1981г, когда обособленную церковь задействуют в исполнении поручений царя. В конце XIX века значительно возрастает вмешательство государства в дела церкви, соборность остается лишь в памяти духовенства [5]. Вследствие того, что церковное управление тяготилось строгим контролем со стороны государственной власти, многие рядовые священники и монахи пользовались огромной популярностью в народе, деликатно выслушивая о житейских проблемах человека и тактично давая советы. Среди таких «провидцев» оказались Оптинские старцы. Благодаря проповедям и открытым беседам с паломниками и прихожанами церковь существенно влияла на нравственность народа, укрепляла веру в Бога, помогала бороться с душевными недугами и наставляла оступившихся людей на верный путь.

Сблизившись с государственными уполномоченными, церковь пыталась стабилизировать и умерять анархические настроения людей, противодействовать смуте и сохранить человеческие ценности. Однако равнодушие к религии неимоверно возрастало, и патриархальная набожность сменялась атеистическими воззрениями. По словам советского историка А.Н. Сахарова «Со снижением авторитета церкви общество теряло важный стабилизирующий фактор» [3].

Благодаря техническому прогрессу и индустриальному росту, человек получает больше возможностей для образования, меньше задействуется ручной труд во всех областях промышленности и строительства, численность городского населения увеличивается. Но оказавшись в центре больших городов, большая часть бывших крестьян теряется, и оказывается неспособной к самостоятельному участию в жизни общества, как физически, так материально и интеллектуально. Духовный мир человека становится скудным, человек перестает страшиться наказания Господня, начинает роптать на жизненные обстоятельства, становится озлобленным и мстительным, совершает множество греховных дел. Внутренний мир человека опустошается, духовные ценности сменяются материальными, главной целью становится зарабатывание денег, обеспечение комфортных условий проживания. В обществе возрастают морально и физически деструктивные деяния такие как коррупция, воровство, убийства, обман, борьба за власть любыми способами [6].

Исследования Т. Гоббса, Ж. Руссо, Н. Бердяева, Э. Фромма, И.А. Ильина, Е. Масуды, Д. Белла относительно свобод человека, человеческого поведения, условий жизни человека в постиндустриальном обществе свидетельствуют о том, что в современном обществе необходимо провести социальные реформы по обеспечению уважения и свобод человека, расширению гарантий прав и безопасности людей. На протяжении нескольких предшествующих веков как отечественные, так и зарубежные ученые, философы, писатели и другие творческие личности акцентировали внимание в своих трудах на снижение качества внутреннего мира человека. Подробно остановимся на духовной составляющей современного мира, внутренней целостности современного человека, постараемся выделить недочеты и благоприятные факторы духовного пути современного человека, рассмотрим мнения разных авторов относительно морально-нравственных проблем человечества. 
Чрезвычайно показателен тот факт, что большая часть населения планеты подвержена психологическим дисфункциям, моральному напряжению, эмоциональному выгоранию, нервным срывам и потрясениям, стрессам и переутомлениям. Это связано, прежде всего, с переизбытком поступающей информации и свидетельствует о том, что человек беззащитен перед воздействием средств массовой информации и не имеет средств и методов защиты от информационных перегрузок. Уместно замечание К.Г. Юнга, швейцарского психиатра и педагога, что «... фактически мы лучше защищены о неурожая, наводнений и эпидемий нежели от нашей духовной несостоятельности, которая очевидно, не в состоянии серьезно сопротивляться психическим эпидемиям» [7]. Следует иметь в виду, что научно-техническая революция в значительной степени обезопасила население стран от природных катаклизмов и способствовала разработке многих видов лекарств для сопротивления человеческого организма микробам и инфекциям, однако, с морально-этической точки зрения чрезмерное количество препаратов и современное медицинское оборудование вводит людей в замешательство и недоверие, страх и панику. Во-первых, каждый препарат имеет побочные действия, во-вторых, до конца не изучено или заведомо умалчивается негативное влияние медицинских аппаратов на клетки человеческого организма (например, излишнее облучение).

Следует также отметить и то, что современная культура внушает подрастающему поколению подражать шаблонной внешности знаменитостей, их манерам и вседозволенному поведению, стремиться к роскоши и богатству, быть яркими, эксцентричными личностями, вычурно ошеломлять и удивлять свое окружение, чтобы стать популярными и даже заработать на причудливом имидже. Общеизвестно, что XXI век отличается от предыдущих обширной сферой услуг и потребления товаров разного предназначения, заметно пропагандируется угождение человеку, услаждение тела и плоти, потакание человеческим желаниям. Отечественный писатель Л.Н. Толстой пытался уберечь читателей и последователей от подобных утех и в своих поучительных трудах писал: «Потакать телу, давать ему лишнее, сверх того, что ему нужно - большая ошибка уже потому, что от роскошной жизни не прибавляется, а уменьшается удовольствие от еды, от отдыха, от сна, от одежды, от помещения. Стал есть лишнее сладкое, не проголодавшись, расстраивается желудок, и нет охоты к еде и удовольствиям. Стал ездить там, где мог пешком пройти, привык к мягкой постели, к нежной, сладкой пище, к роскошному убранству в доме, привык заставлять делать других, что сам можешь сделать, - и нет радости от отдыха после труда, тепла после холода, нет крепкого сна и все больше ослабляешь себя и не прибавляешь, а убавляешь радости и спокойствия, и свободы» [8]. Надо полагать, что мышление современного человека в значительной степени искажено, также как и представления о счастье и смысле жизни. По мнению русского философа И.А. Ильина: «Грозная беда постигла современное человечество: оно расшатало духовные основы своего бытия, заглушило в себе главную религиетворящую силу духа - сердечное созерцание и растеряло свои святыни» [9].

Заслуживает внимания работа исследователей Н.И. Мешкова, Д.Н. Мешкова относительно проблемы духовности в научном и религиозном понимании. Данные ученые разделяют понятие духовности в православном понимании и духовности как результата научного образования. Однако, если в основе духовности заложена любовь и чувство гуманности, то «религиозное познание является более сложным явлением, чем научное познание. Поскольку одна из задач веры состоит в том, чтобы взрастить и укрепить веру человека, любовь и надежду на вечное спасение» [10].

Уместно обратить внимание на зрелость человека и готовность брать на себя ответственность за свои поступки и слова. В эпоху обширного выбора удовольствий и развлечений, всевозможных вспомогательных приспособлений для домашнего убранства, упрощенного и быстрого получения товаров и услуг, информации, современный человек все же претерпевает множество душевных терзаний, впадает в депрессивные состояния, чувствует себя одиноким и покинутым, теряется, когда предстоит что-то выбрать или принять верное решение. Человек начинает сомневаться, нервничать, затрачивает огромное количество сил и энергии на обдумывание важных вопросов и, тем не менее, оказывается не способным решиться на ответственный шаг или даже сделать попытку что-либо поменять в своей жизни, откладывая действие на будущее. Как заметил священнослужитель Православной церкви А.Д. Шмеман в своих дневниках относительно отрицания перемен и новых состояний: «Новая ситуация неверна, плоха, только потому что она новая. И это априорное ее отрицание не позволяет даже понять ее, оценить в категориях веры и по-настоящему «встретить» ее. Уход и отрицание, но никогда не понимание» [11]. Абсолютно верное замечание, касающееся веры и доверия Вселенной, в благополучный исход дела, отказ от самостоятельного размышления и обдумывания ситуации, убегание от ответственности и лень. К сожалению, такие понятия как дисциплина, упорство, воля, терпение и смирение, послушание - чужды современному человеку.

Уместно отмечает М. Хайдеггер, что современному человеку свойственно все упрощать и облегчать, обходить трудноразрешимые вопросы и отмалчиваться при возникновении спорных ситуаций. Следуя данному примеру, можно говорить о незрелости человека, в частности духовной. [12]. При этом, как правило, ощущается чувство безысходности, обреченности, брошенности и тогда же происходит некоторое пробуждение сознания или поиск ответов на накопившиеся вопросы, когда че- 
ловек может запутаться в своих домыслах и попасться на уловки мошенников, а также поддаться искушению быть услышанным псевдоспециалистами - неопытными психологами, шаманами, ведуньями и экстрасенсами. Вероятно, на интуитивном уровне человек начинает искать легкие способы разрешения своих бед, но через посредников, которые обладают неведомой силой свыше, прибегают к языческим обрядам. По мнению И.А. Ильина: «Если у такого человека проснется «религиозная потребность», то она поведет к недуховной и противодуховной религиозности» [9]. К сожалению, вместо душевного поиска чистоты, святости, бережности, человек начинает скучать, терять контроль над собой, уходя в пьянство, разврат, хандру и даже заканчивая жизнь самоубийством. Уместно обращает внимание французский философ А. Камю в своем творчестве: «Свести счеты с жизнью - означает признаться, что бытие больше не поддается пониманию: явственно осознается только его конец» [13]. Очевидно, что автор подразумевает о некотором застойном явлении в жизни человека, состояние безысходности и удрученности, наскучившей рутине и однообразному образу жизни. Основная масса людей живет по определенному шаблонному мышлению, приспосабливается к неудовлетворяющим душу человека условиям, диктуемым политической властью, оправдывает свое бездействие и безынициативность. Таким образом, человек начинает чувствовать себя заложником политических игр, экономических дебатов, общественного мнения, а также изгнанником в определенных группах или сообществах, тем самым укореняя в себе самом слабость к противодействию и познанию мирового устройства и поиску гармоничного состояния. А. Камю уточнял в своих трудах, что «...Воля является двигателем и направлена на укрепление сознания. Воля упорядочивает жизнь... А печаль обычно возникает по двум причинам: из-за незнания или несбыточности надежд» [13].

Остается невыясненным вопрос о том, что должно произойти, чтобы человек самостоятельно увидел свою духовную несостоятельность или как прийти к духовности современному человеку? Бесспорен факт, что особый уровень духовности есть у каждого человека, который проявляется в отношении к вещам и жизненным проблемам. И случается, что даже в одной семье родственники имеют личный уровень духовного просветления. Опасность появляется, когда человек «одухотворенный» впадает в тщеславие и гордыню, для него теряют значимость авторитеты, ученые, мудрецы. Как следствие, человек может плавно опуститься до грехопадений. Насущно А. Камю задавался вопросом: «Стоит ли бунтовать, если в тебе самом нет ничего постоянного, достойного сохранения?» [14]. Бунтующий человек живет, не руководствуясь сердцем, а расчетливым разумом и памятью. Не зависимо от социального статуса и нравственного воспитания, любой человек может дойти до абсурда и впасть в отчаянье. Именно этот момент явля- ется ключевым в жизни современных людей, когда человеческая душа жаждет очищения от страстей, пошлости, самоистязания и самоуничижения.

Обобщая все вышесказанное, приходим к выводу, что духовную культуру требуется подпитывать, как и воспитывать в себе дух. Приведем примеры не только церковного, но и светского духовного очищения: молитвенные службы в храме, чтение духовной литературы, умиление от прослушивания классической музыки, мысленное обращение к высшим силам, просмотр духовных документальных фильмов, чтение философских текстов и трактатов, увлечение живописью и архитектурой, просмотр театральных постановок и репродукций и многое другое. Молиться, познавать, созерцать - то, к чему нужно стремиться каждому человеку, находить очаги духовного просвещения, помышлять доброе и творить милосердие. Очевидно, что обыденное и примитивное откроется человеку иначе, окажется обновленным и даже священным. Соединение с природой является неотъемлемой составляющей горожан. Занимаясь самопознанием и регулярно открывая для себя источники радости и вдохновения, человек выходит на новый уровень сознания, умело преодолевает препятствия и смело шагает навстречу трудностям, дабы повысить свое мастерство и укрепить силу духа. Таким образом, человек привыкает видеть целостную картину мира и осознает свое место в ней. «Отсюда правило всякого воспитателя: надо пробудить у ребенка как можно раньше духовное око, око любви, око совести, вкус к совершенству...», - утверждал И.А. Ильин, чтобы последующие поколения не были обречены на погибель и истребление [9].

В самом деле, если исходить из общей современной ситуации, замечателен факт, что современное общество пронизано духовными противоречиями. Старшее поколение более религиозно, борется за очищение и вовлечение народа в духовную сферу. Однако, изучив понятие духовности в новых условиях, важно отметить, что не следует быть воцерковленным и богобоязненным, потому что так принято, а научиться видеть Божий замысел в каждом действии и во всех сферах жизни, начиная с личной жизни и заканчивая государственной службой.

В заключение следует отметить, что мудрость духовного развития человека заключается в том, чтобы в человеке было нарушено тщеславие, гордыня и самодовольство. Духовная неудовлетворенность выравнивает человека и мотивирует на постижение духовного наполнения, преодоление тоски, ропота, учит человека критически относится к себе и происходящим событиям, придавая им духовно-плодотворный смысл. Поэтому обозначив ситуацию с духовной составляющей, каждый человек сам выбирает каким путем ему следовать и насколько важно вести духовный образ жизни среди мирского населения. 


\section{ЛИТЕРАТУРА}

1. Энциклопедия мудрости: [12+] / [ред.-изд. группа: Г. Кирияк и др.]. - М.: РОOCCA, 2014. - 814 с.: ил.; 26 см.; ISBN 978-5-91926-189-6.

2. Сахаров А.Н. История России с древнейших времен до конца XVII века / А.Н. Сахаров, А.П. Новосельцев и др. - М.: 000 «Издательство АСТ», $2000 .-576 c$. - ISBN 5-237-02246-4.

3. Сахаров А.Н. История России: С начала XVIII до конца XIX в. / А.Н. Сахаров, Л.В. Милов и др. - М.: 000 «Фирма «Издательство ACT», 2001. - 544c. - ISBN 5-17-009096-X.

4. Лютер М.0 свободе христианина / Составление, вступ. статья, пер. с нем., коммент., примеч. Ивана Фокина. - Уфа: «ARC», 2013. — 728 c. ISBN 978-5905551-05-5.

5. Чуринов Н.М. Совершенство и свобода: монография / Н.М. Чуринов. - Новосибирск: Изд-во СО РАН. - 2006. - 712 с. ISBN 5-7692-0826-0.

6. Фромм Э. Бегство от свободы / Эрих Фромм; Пер. с англ. Г.Ф. Швейника; 0бщ. ред. и послесл. [с. 248-267] П.С. Гуревича. - М.: Прогресс, 1990. - 269 с. ISBN 5-01-001914-0.

7. Юнг К.Г. О психологии восточных религий и философий: [перевод] / Карл-Густав Юнг; [Московский философский фонд]. - Москва: Московский философский фонд: Медиум, 1994. - 253, [2] с.: ил.; 19 см. - (ППР. Первые публикации в России).; ISBN 5-85691-010-9.

8. Толстой Л.Н. Путь жизни / Л.Н. Толстой; [Послесл. Ю.Н. Давыдова; Примеч. Р.К. Медведевой]. - М.: Республика, 1993. - 430 [1] с.; 23 см. - (Библиотека этической мысли).; ISBN 5-250-01940-4.

9. Ильин И.А. Аксиомы религиозного опыта: Исследование: Т. 1-2 / И. А. Ильин; [Сост. и авт. вступ. ст., с. 3-33, И. Н. Смирнов]. - М.: Т00 «Рарогъ», 1993. - 448 с.; 23 см.; ISBN 5-87372-014-2.

10. Мешков Н.И. Духовность В научном и религиозном понимании / Н.И. Мешков, Д.Н. Мешков // Гуманитарий: актуальные проблемы гуманитарной науки и образования. - 2019. - №1. - с. 69-78; ISSN 2078-9823.

11. Шмеман А.Д. Исторический путь православия / Прот. А. Шмеман. - [Репринт. изд.]. - М.: Паломник, 1993. - 387 [2] с.; 17 см.; ISBN 5-87468-014-4

12. Хайдеггер М. Время и бытие: статьи и выступления / Мартин Хайдеггер; [сост., пер., вступ. ст., коммент. и указ. В.В. Бибихина]. - Москва: Республика, 1993. - 445 [2] с.; 22 см. - (Мыслители XX века).; ISBN 5-250-01496-8.

13. Камю А. Миф о Сизифе / Альбер Камю; [пер. с фр. С. Великовского]. - Москва: АСТ: Астрель, 2011. - 218, [2] с.; 17 см. - (Философия. Психология).; ISBN 978-5-17-071670-8.

14. Камю А. Бунтующий человек: Философия. Политика. Искусство: [Сборник: Пер. с фр.] / Альбер Камю; [0бщ. ред., сост. и предисл., с. 5-22, А.М. Руткевича]. - М.: Политиздат, 1990. - 414 [1] с.; 22 см. - (Мыслители XX в. Редкол.: Т.И. Ойзерман (пред.) и др.).; ISBN 5-250-01279-5.

(с Гринева Ольга Александровна (gold23@inbox.ru).

Журнал «Современная наука: актуальные проблемы теории и практики» 